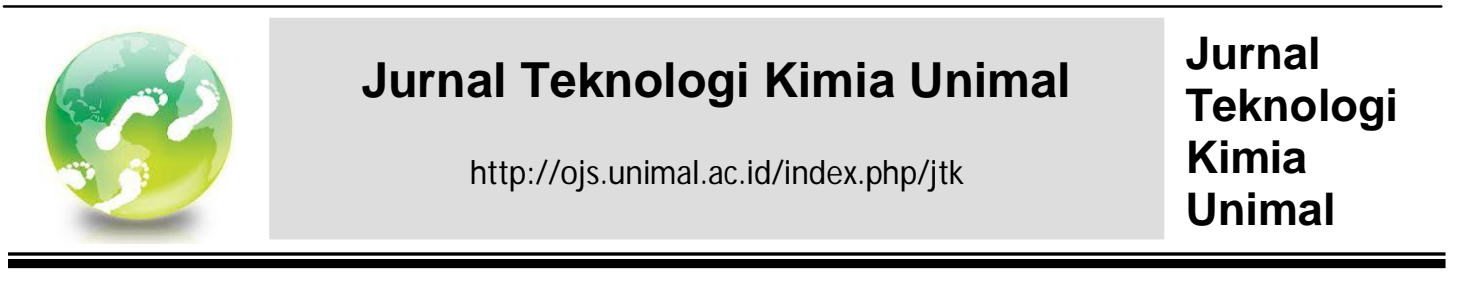

\title{
PEMANFAATAN GETAH RUMBIA SEBAGAI PEREKAT PADA PROSES PEMBUATAN BRIKET ARANG TEMPURUNG KELAPA
}

\author{
Muhammad, Ishak, Nani Lidia \\ Jurusan Teknik Kimia, Fakultas Teknik, Universitas Malikussaleh \\ Kampus Utama Cot Teungku Nie Reuleut, Muara Batu, Aceh Utara - 24355 \\ e-mail:mhdtk@unimal.ac.id
}

\begin{abstract}
Abstrak
Penelitian pembuatan briket dari tempurung kelapa yang menggunakan getah rumbia sebagai perekat telah selesai dilakukan. Penelitian ini bertujuan untuk mengkaji kelayakan getah rumbia sebagai bahan perekat dan memanfaatkan limbah tempurung kelapa sebagai bahan baku pembuatan briket, yang selanjutnya dapat meningkatkan perekonomian masyarakat pendesaan. Penelitian ini dilakukan melalui beberapa tahapan proses yaitu pengumpulan bahan baku, pengeringan bahan baku, karbonisasi tempurung kelapa, pengecilan ukuran bahan dan pemisahan berdasarkan ukuran (pengayakan). Setelah penyiapan karbon tempurung dilakukan, maka getah rumbia digunakan sebagai perekat dalam pembuatan adonan briket arang tempurung. Proses selanjutnya adalah pencetakan, pengempaan dan pengeringan briket. Penentuan mutu briket yang telah dikeringkan meliputi kadar air, laju pembakaran dan nilai kalor dengan perbandingan arang-perekat adalah 2:1, 4:1 dan 6:1. Kadar air yang diperoleh berkisar antara 6,4-8,4\%, laju pembakaran berkisar antara 0,052-0,07 gr/min, sedangkan nilai kalor yang didapat bervariasi terhadap mesh karbon yang digunakan, yaitu untuk 50 mesh adalah 26651 kal/gram, sedangkan untuk 80 mesh adalah $29327 \mathrm{kal} / \mathrm{gram}$.
\end{abstract}

Kata kunci: briket, getah rumbia, tempurung kelapa, karbonisasi.

\section{Pendahuluan}

Krisis energi merupakan permasalahan dunia saat ini. Tiap tahunnya kebutuhan energy semakin meningkat seiring dengan meningkatnya aktivitas manusia yang menggunakan bahan bakar, terutama bahan bakar berbasis fosil. Keterbatasan persediaan bahan bakar fosil yang semakin menipis mengakibatkan kenaikan harga, oleh karena itu diperlukan suatu alternative untuk mengurangi penggunaan bahan bakar minyak (BBM). Maka dari itu, salah satu alternative yang dipilih adalah pemamfaatan limbah dan penggunaan energy biomassa. 
Biomassa yang dijadikan sebagai bahan bakar alternative tentulah yang bersifat ramah lingkungan, mudah diperoleh, lebih ekonomis dan dapat digunakan oleh masyarakat luas.

Bahan bakar berbasis biomassa dapat diperoleh dari limbah pertanian, limbah industri, limbah rumah tangga dan lain-lain. Dalam upaya pemanfaatannya sebagai bahan bakar maka limbah tersebut harus diolah terlebihdahulu menjadi bahan bakar padat dalam bentuk briket. Masing-masing bahan memiliki sifat tertentu untuk dimanfaatkan sebagai briket namun yang paling penting adalah bahan tersebut harus memiliki sifat termal yang tinggi dan emisi $\mathrm{CO}_{2}$ yang dihasilkan rendah sehingga tidak berdampak pada pemanasan global. Diantara bahan yang memiliki sifat tersebut yaitu tempurung kelapa yang memiliki sifat difusi termal yang baik dan dapat menghasilkan kalor sekitar 6500-7600 kkal/kg (Triono, 2006).

Penyebaran tanaman kelapa di Indonesia yang banyak serta banyaknya industry kecil dan rumah tangga yang menggunakan bahan dasar kelapa mengakibatkan limbah tempurung kelapa semakin meningkat. Oleh karena itu dengan penggunaan tempurung kelapa sebagai bahan pembuatan briket dapat mengatasi permasalahan limbah. Pemanfaatan tempurung kelapa sebagai bahan pembuatan briket dapat memperbaiki penampilan dan mutu tempurung sehingga akan meningkatkan nilai ekonomis tempurung kelapa. Di samping material sebagai precursor pembuatan briket, perekat juga sangat menentukan kualitas produk briket yang akan dihasilkan.

Pada penelitian sebelumnya, para peneliti melakukan penyelidikan untuk memperbaiki kinerja briket dengan memvariasikan bahan pengikat yang berbeda seperti kanji, sagu, tanah liat, semen, natrium silikat dan tetes tebu (molase) dan lain-lain. Sutiyono (2002) membandingkan antara perekat kanji dengan perekat tetes tebu dan dihasilkan briket yang optimum yaitu briket yang menggunakan bahan perekat kanji karena memiliki kuat tekan dan nilai kalor yang lebih tinggi. Lestari, dkk (2010) juga melaporkan hasil kajian mereka yaitu membandingkan antara perekat sagu dan perekat kanji. Berdasarkan penelitian tersebut mereka menginformasikan bahwa perekat kanji lebih baik dibandingkan sagu, karena 
perekat kanji memiliki kandungan air dan abu yang rendah dan karbon yang lebih tinggi dibandingkan dengan perekat sagu.

Tujuan penelitian ini adalah melakukan satu kajian kelayakan penggunaan getah rumbia sebagai bahan pengikat pada proses pembuatan briket dari bahan dasar tempurung kelapa. Penelitian ini juga dilakukan untuk mengevaluasi pengaruh variasi konsentrasi perekat getah rumbia terhadap kadar air, nilai kalor dan laju pembakaran briket.

\section{Bahan dan Prosedur}

\subsection{Bahan}

Bahan yang digunakan dalam penelitian ini adalah tempurung kelapa, getah rumbia dan akuades. Peralatan yang digunakan adalah gelas ukur, pipet tetes, kaca arloji, tanur karbonisasi, alat pengecilan ukuran (crushing), ayakan 50 dan 80 mesh, neraca analitik, oven, cawan porselin, pencetak briket dan desikator.

\subsection{Prosedur}

Prosedur penelitian ini dimulai dari pembersihan bahan baku, dimana tempurung kelapa dibersihkan terlebih dahulu dari bahan pengotor seperti tanah dan kotoran-kotoran lain yang menempel pada tempurung. Selanjutnya tempurung dihancurkan menjadi ukuran yang lebih kecil untuk memudahkan proses karbonisasi. Tempurung kemudian dikeringkan di bawah sinar matahari untuk mengurangi kandungan air dari tempurung. Selanjutnya tempurung kelapa yang sudah kering diambil sebanyak $1 \mathrm{~kg}$ untuk dikarbonisasi. Proses pembakaran ini dibiarkan berlangsung selama 3 jam. Selanjutnya arang didinginkan selama 1 jam dan dilakukan penyortiran. Arang yang telah terbentuk dari proses karbonisasi selanjutnya dihaluskan dengan menggunakan mesin crushing dan diayak sehingga diperoleh serbuk arang dengan ukuran 50 dan 80 mesh.

Setelah itu arang tempurung kelapa dicampur dengan getah rumbia dengan kadar $10 \%$ dari berat arang, diaduk menjadi adonan sampai merata. Setelah merata, campuran tersebut dimasukkan ke dalam alat pencetak briket. Hasil adonan briket diletakkan pada cetakan berbentuk silindris dengan tinggi $6 \mathrm{~cm}$ dan diameter $3 \mathrm{~cm}$ kemudian dipadatkan dengan menggunakan mesin pencetak briket 
bertenaga hidrolik. Briket arang yang dihasilkan kemudian dikeringkan dalam oven pada suhu $105{ }^{\circ} \mathrm{C}$ selama 2 jam. Briket yang telah dikeringkan dikemas dalam kantong plastik dan ditutup rapat untuk menjaga agar briket tetap dalam keadaan kering.

Penentuan mutu briket pada penelitian ini meliputi penentuan kadar air dan analisa nilai kalor dengan menggunakan bom calorimeter. Prosedur masingmasing tahapan kerjanya adalah sebagai berikut:

a. Penentuan Kadar Air (SNI 06-3730-1995)

Kadar air briket dapat ditentukan dengan cara menimbang cawan porselin kosong kemudian sampel briket dimasukkan ke cawan sebanyak 5 gram. Sampel dimasukkan ke dalam oven yang telah diatur suhunya, yaitu $105^{\circ} \mathrm{C}$ sampai berat tetap. Cawan dikeluarkan dari oven dan didinginkan dalam desikator kemudian ditimbang bobotnya. Penentuan kadar air dilakukan sebanyak tiga kali pengulangan. Kadar air dapat ditentukan dengan menggunakan persamaan (1) (Obi, 2015).

$$
\text { Kadar air }(\mathrm{KA})=\frac{W a-W b}{W a} x 100 \%
$$

dimana KA adalah nilai kadar air (\%), Wa = Bobot sebelum pengeringan (gram) dan $W \mathrm{~b}=$ Bobot setelah pengeringan (gram).

\section{b. Penentuan Laju pembakaran}

Laju pembakaran adalah kecepatan briket tempurung kelapa terbakar habis sampai menjadi abu. Pengujian lama nyala api dilakukan dengan cara briket dibakar dan dilalukan pencatatan waktu dengan menggunakan stopwatch mulai ketika briket menyala hingga briket menjadi abu. Persamaan (2) digunakan untuk menentukan laju pembakaran (Santosa dkk, 2010).

$$
\text { Laju pembakaran }(\mathrm{gr} / \mathrm{menit})=\frac{x}{y}
$$

dimana berat briket tempurung kelapa adalah $x$ (gram) dan $y$ adalah waktu yang dibutuhkan sampai briket terbakar habis (menit)

c. Analisa Kalori/Nilai Bakar 
Untuk penentuan besarnya nilai bakar yang dihasilkan oleh briket dari tempurung kelapa dengan menggunakan getah rumbia sebagai perekat, maka analisanya dilakukan dengan menggunakan bom kalorimeter.

\section{Hasil dan Diskusi}

Untuk meningkatkan penggunaan tempurung kelapa sebagai bahan bakar alternatip, maka tempurung kelapa dapat diolah menjadi briket. Tempurung kelapa yang akan dijadikan briket harus tempurung yang berasal dari kelapa yang sudah tua, kering dan bersih dari pengotor seperti serabut, tanah ataupun pasir yang menempel pada tempurung karena akan berpengaruh pada saat proses karbonisasi dan mutu briket yang dihasilkan. Tempurung yang basah (moisturnya tinggi) akan menimbulkan banyak asap pada saat dilakukan karbonisasi.

Proses karbonisasi pada penelitian ini dilakukan menggunakan drum dengan sistem sederhana. Tujuannya adalah agar terjadi pirolisis, sehingga tidak terjadi pembakaran lebih lanjut/sempurna pada tempurung kelapa. Akibat dari itu menghasilkan rendemen arang yang diperolehnya tinggi karena terbentuk arang secara sempurna dan hanya menyisakan sedikit abu.

Arang yang terbentuk dari proses karbonisasi digiling dengan menggunakan mesin penggiling yang tujuan adalah untuk memperkecil ukuran partikel arang karena ukuran partikel arang juga mempengaruhi kualitas briket yang dihasilkan. Serbuk arang diayak dengan ayakan 50 dan 80 mesh sesuai dengan SNI 01-62352000.

Getah rumbia digunakan sebagai bahan perekat pada penelitian ini didasarkan pada beberapa pertimbangan diantaranya getah rumbia mudah diperoleh, dan dapat menghasilkan kekuatan rekat kering yang tinggi serta menghasilkan sedikit asap saat dibakar. Selain itu, pada saat briket dibakar getah akan terdekomposisi sehingga membentuk pori-pori yang memudahkan terperangkapnya udara. Dengan adanya udara dalam pori-pori tersebut maka briket akan mudah terbakar dengan sempurna.

Hasil adonan serbuk arang dengan perekat getah rumbia dicetak dan ditekan dengan menggunakan cetakan manual. Tujuan pencetakan yaitu memperbaiki penampilan dan tekstur dari briket serta mempermudah dalam penggunaan 
terutama pada pembakaran dan pengemasan. Pemberian tekanan akan menyebabkan perekat yang masih dalam keadaan cair akan mulai tersebar secara merata ke dalam celah-celah dan keseluruhan permukaan serbuk arang yang menyebabkan ikatan antar parikel arang semakin kuat sehingga briket yang dihasilkan tidak mudah rapuh (Maryono dkk, 2013). Briket yang dihasilkan berbentuk silinder dengan tinggi $6 \mathrm{~cm}$ dan diameter $3 \mathrm{~cm}$. Pengeringan briket dilakukan dalam oven pada suhu $105^{\circ} \mathrm{C}$ selama 3 jam untuk mengurangi kandungan air briket yang berasal dari perekat yang digunakan. Briket yang telah kering dikemas di dalam kantongan agar briket tetap kering karena briket arang bersifat higroskopis sehingga jika dibiarkan di udara terbuka maka briket akan menyerap uap air dari udara sekitar yang menyebabkan briket menjadi lembab dan susah dinyalakan (Maryono dkk, 2013).

\subsection{Efek komposisi terhadap kadar air}

Salah satu faktor yang mempengaruhi kualitas briket yang dihasilkan adalah banyaknya kandungan air di dalam briket. Briket dengan kandungan air yang rendah akan mudah terbakar dan juga mampu menghasilkan nilai kalor yang tinggi. Berdasarkan hasil pengujian persentase kadar air pada briket menunjukan bahwa semakin besar persentase perekat yang dicampurkan dengan serbuk arang maka persentase kadar airnya semakin meningkat.

Gambar 1 dan 2 terlihat bahwa semakin rendah kadar serbuk arang (karbon) maka kadar air yang dihasilkan semakin tinggi. Maryono, dkk (2013) melaporkan bahwa pada penambahan perekat yang semakin tinggi menyebabkan air yang terkandung dalam perekat akan masuk dan terikat dalam pori arang. Dalam penelitiannya tentang analisis mutu briket dengan perekat kanji melaporkan hal yang sama yaitu semakin tinggi kadar perekat maka kadar air yang diperoleh semakin tinggi pula. Selain itu penambahan perekat yang semakin tinggi akan menyebabkan briket mempunyai kerapatan yang semakin tinggi pula sehingga pori-pori briket semakin kecil dan pada saat dikeringkan air yang terperangkap di dalam pori briket sukar menguap. 


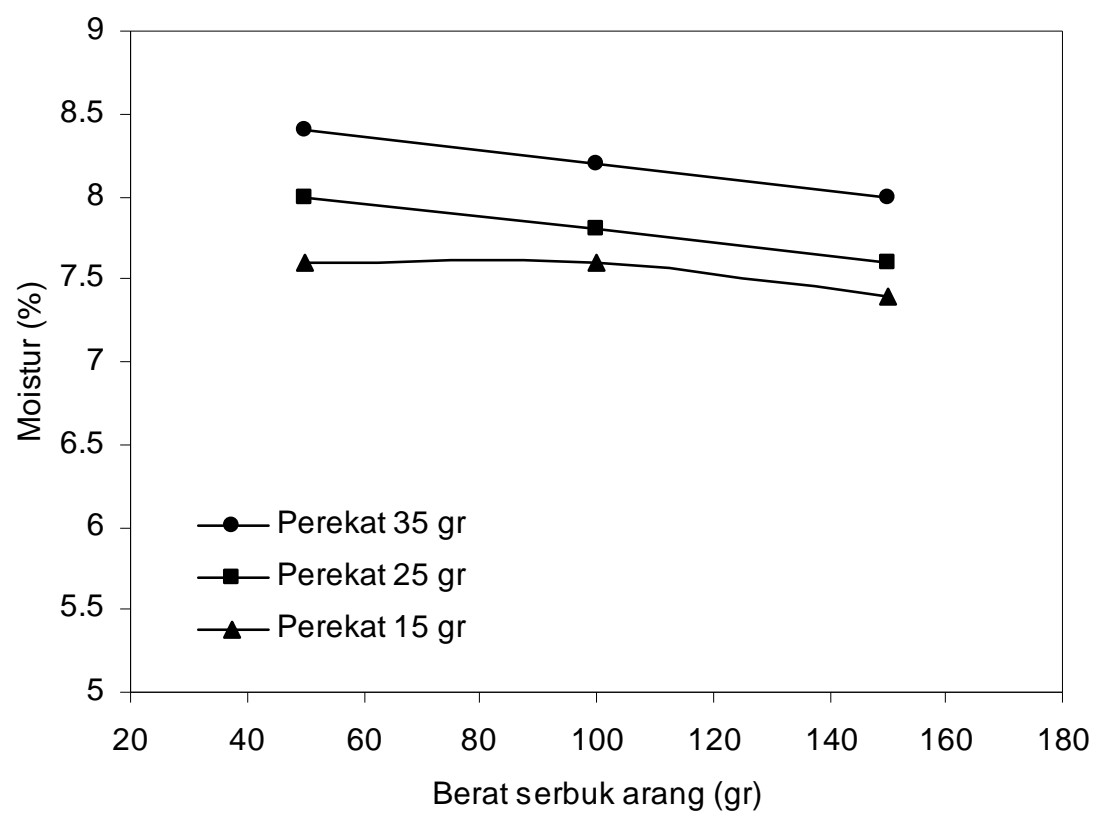

Gambar 1. Hubungan berat arang terhadap kadar air pada briket arang tempurung kelapa, untuk serbuk arang berukuran 50 mesh.

Gambar 1 menggunakan serbuk arang ukuran 50 mesh dengan berat 150 gram memperlihatkan bahwa penggunaan perekat getah rumbia dengan kadar 15 gram memiliki persentase moistur yang lebih rendah, yaitu $7,4 \%$ sedangkan untuk berat perekat 25 gram adalah $7,6 \%$ dan diikuti oleh berat perekat 35 gram yang memiliki moistur 8\%. Dibandingkan dengan Gambar 2 yang menggunakan serbuk arang dengan ukuran 80 mesh moisturenya lebih rendah yaitu 6,4\% untuk berat perekat 15 gram dan 7,4\% untuk berat perekat 15 gram, kecuali untuk berat perekat 35 gram adalah sama yaitu $8 \%$. Sesuai dengan sifatnya bahwa arang memiliki kemampuan menyerap air dari udara di sekelilingnya (sifat higroskopis). Selain dari itu, kemampuan menyerap air juga dipengaruhi oleh luas permukaan dan pori-pori arang. 


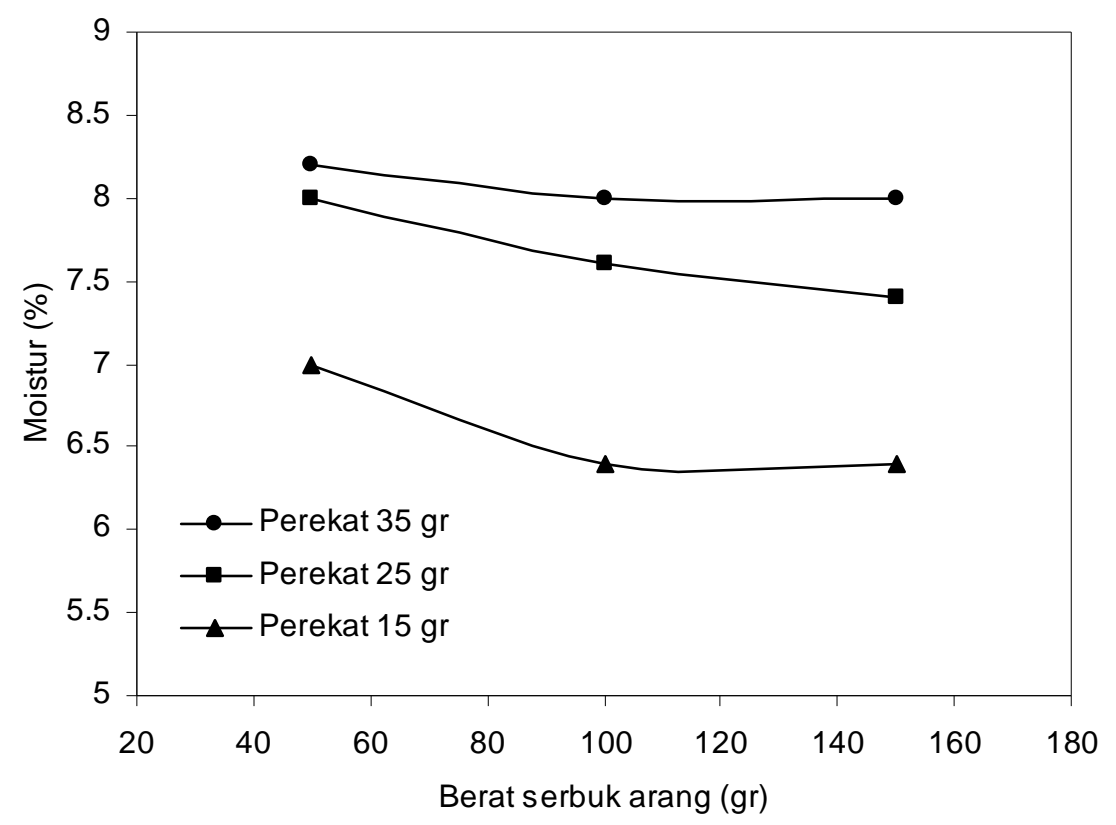

Gambar 2. Hubungan berat arang terhadap kadar air pada briket arang tempurung kelapa, untuk serbuk arang berukuran 80 mesh.

Grafik pada Gambar 1 dan 2 dapat dikatakan bahwa briket arang yang menggunakan getah rumbia sebagai perekat memiliki kadar air yang sudah memenuhi standar SNI, dimana briket arang yang baik memiliki kadar air maksimum $8 \%$, sedangkan dari hasil pengujian dalam penelitian ini memiliki kadar air rata - rata $<8 \%$, seperti yang diperlihatkan pada Gambar 1 dan 2. Selain dari itu, kadar air dalam briket dipengaruhi oleh jenis bahan baku, jenis perekat dan pengepresan disaat pembentukan briket yang dilakukan secara manual. Pada umumnya kadar air yang tinggi akan menurunkan nilai kalor dan laju pembakaran karena panas yang diberikan digunakan terlebih dahulu untuk menguapkan air yang terdapat di dalam briket. Briket yang mengandung kadar air yang tinggi akan mudah hancur/lebur serta mudah ditumbuhi jamur (Maryono, dkk, 2013).

\subsection{Efek komposisi terhadap laju pembakaran}

Salah satu hal yang harus diketahui pada proses pembuatan briket adalah laju pembakaran. Pengamatan daya bakar juga perlu dilakukan untuk mengetahui lama waktu terbakarnya bahan, yaitu dengan membakar briket hingga muncul bara. Perhitungan waktu dimulai pada saat briket membara hingga menjadi debu. 
Disisi lain, daya bakar briket arang sangat perlu diuji karena hal ini akan menunjukkan seberapa besar penggunaan bahan bakar, semakin lama briket arang habis maka semakin sedikit bahan bakar yang di gunakan dan semakin kecil pengeluaran biaya untuk bahan bakar.

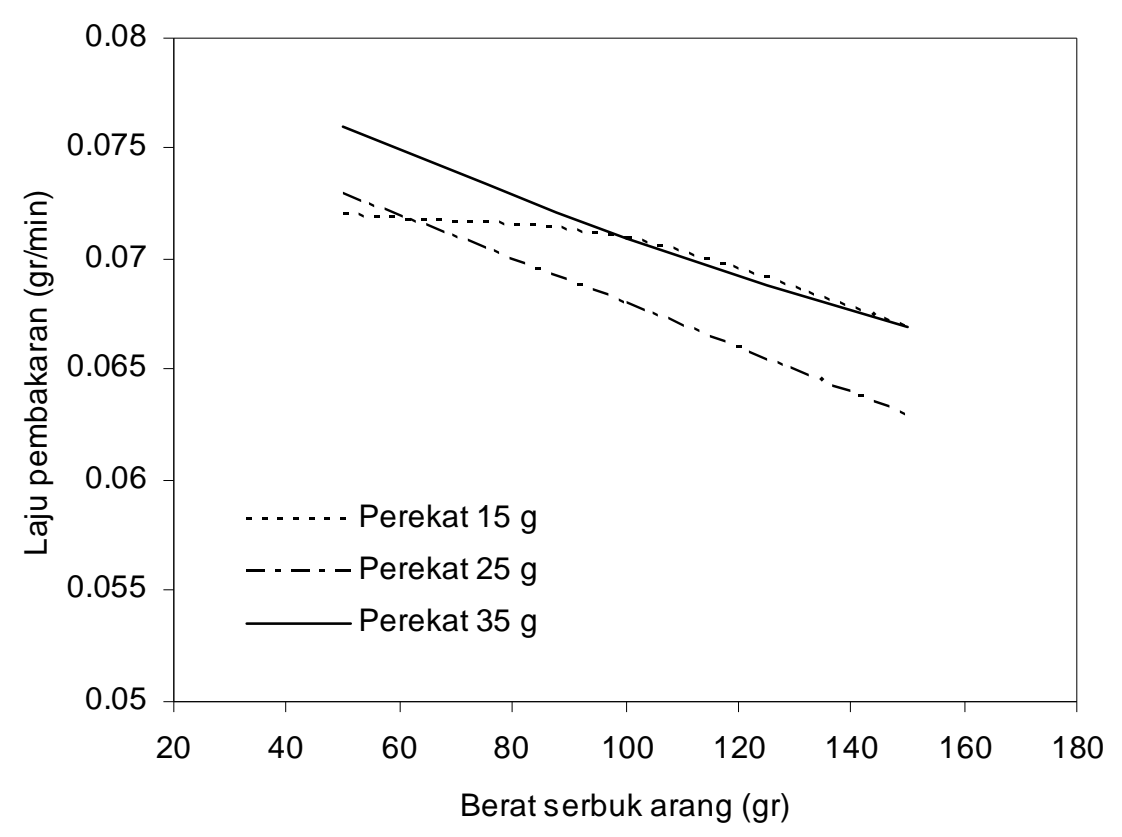

Gambar 3. Grafik hubungan kadar serbuk arang terhadap laju pembakaran briket arang tempurung kelapa, untuk arang berukuran 50 mesh.

Laju pembakaran paling cepat diperoleh pada komposisi pembuatan briket dengan perlakuannya; karbon tempurung kelapa 50 gram yang ukurannya 50 mesh dengan berat perekat 35 gram adalah sebesar 0,076 gr/menit, sedangkan laju pembakaran paling lama diperoleh pada perlakuan kadar serbuk karbon tempurung kelapa 150 gram dengan penggunaan perekat getah rumbia 35 gram dan ukuran partikel arang 80 mesh yaitu 0,052 gr/menit (Gambar 3 dan Gambar 4). Jika dibandingkan dengan laju pembakaran briket dengan berat arang tempurung yang digunakan maka laju pembakaran dengan menggunakan berat arang tempurung kelapa 150 gram lebih cepat. Waktu yang dibutuhkan untuk pembakaran briket dengan ukuran arang 50 mesh adalah 92 menit, sedangkan untuk briket dengan ukuran arang 80 mesh adalah 135 menit. 


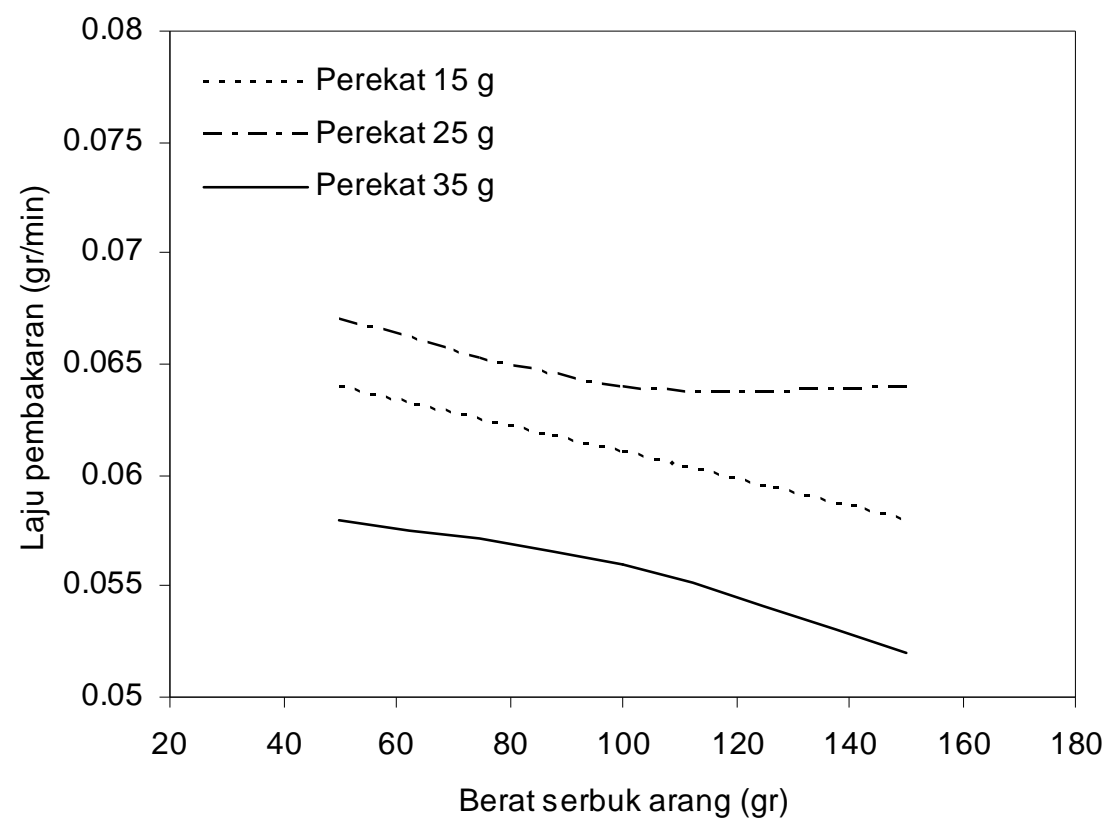

Gambar 4. Grafik hubungan kadar serbuk arang terhadap laju pembakaran briket arang tempurung kelapa, untuk arang berukuran 80 mesh.

Gambar 3 dan Gambar 4 menunjukkan bahwa laju pembakaran briket yang dibuat dari serbuk arang tempurung berukuran 80 mesh dimana rata-rata lama pembakarannya yaitu 135 menit atau 0,067 gr/menit. Laju pembakaran briket yang dibuat dari serbuk karbon berukuran 50 mesh dimana rata-rata lama laju pembakarannya yaitu 93 menit atau 0,076 gr/menit. Laju pembakaran briket juga bertambah cepat dengan ukuran partikel arang yang lebih besar (50 mesh) dibandingkan dengan penggunaan arang dengan ukuran partikel yang lebih kecil (80 mesh). Salah satu alasannya adalah ukuran partikel briket yang lebih besar akan menghasilkan rongga udara yang lebih besar atau kerapatan yang rendah sehingga diffusi udara lebih lancar dan proses pembakaran rnenjadi lebih mudah (Hapis dan Bisrul, 2008). Selain dari itu, kecepatan pembakaran juga dipengaruhi oleh struktur bahan, kandungan karbon terikat dan tingkat kekerasan bahan. Secara teoritis jika kandungan senyawa volatilnya tinggi maka briket akan mudah terbakar dengan kecepatan pembakaran yang tinggi (Ristianingsih, 2015). 


\subsection{Nilai Kalor}

Nilai kalor briket arang merupakan salah satu sifat/parameter penting dan utama dalam menentukan kualitas, serta kelayakan briket arang untuk digunakan sebagai bahan bakar. Kandungan energi pada briket bergantung pada komposisi kimianya dan kadar airnya, jadi semakin tinggi nilai kalor suatu briket maka makin tinggi pula kualitas dan harga jualnya.

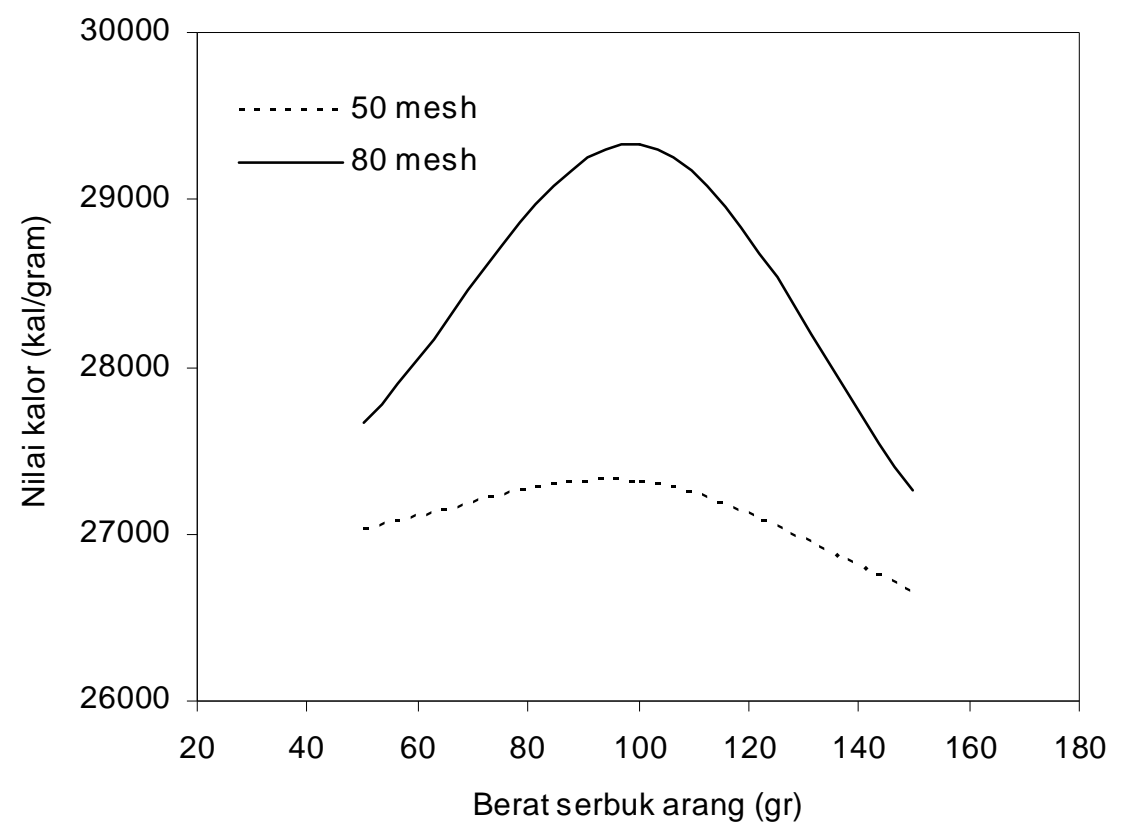

Gambar 5. Grafik hubungan kadar serbuk arang terhadap nilai kalor briket arang tempurung kelapa, untuk arang berukuran 80 dan 50 mesh.

Gambar 5 memperlihatkan hasil analisa nilai kalor dengan menggunakan bomb calorimeter. Grafik pada Gambar 5 melukiskan bahwa nilai optimum yang didapat pada perbandingan adonan serbuk arang dengan perekat adalah 4:1 (100:25). Hal ini disebabkan oleh meratanya pendistribusian serbuk arang yang ada dalam produk briket. Di samping itu, perbandingan adonan yang sesuai dan pendistribusian serbuk arang yang merata, disertai dengan terjadinya dekomposisi perekat maka pembakaran berlangsung sempurna sehingga mengakibatkan nilai bakar briket tersebut semakin tinggi. 
Nilai kalor untuk masing-masing adonan dan masing-masing mesh ditabulasikan dalam Tabel 1. Variasi data pada Tabel 1 memperlihatkan besarnya nilai kalor untuk karbon berukuran 50 mesh dengan adonan 100 gr karbon dan 25 gr perekat adalah sebesar 26651 kalori/gram, sedangkan untuk karbon berukuran 80 mesh didapat nilai kalornya adalah sebesar 29327 kalori/gram. Hubungan komposisi briket dengan laju pembakaran briket dapat dilihat pada Tabel 1, besarnya laju pembakaran berada dalam rentang nilai dari $26651 \mathrm{kal} / \mathrm{gram}$ hingga $29327 \mathrm{kal} / \mathrm{gram}$.

Tabel 1. Hasil analisis nilai kalor pada briket tempurung kelapa ditinjau dari ukuran karbon.

\begin{tabular}{cccc}
\hline $\begin{array}{c}\text { Ukuran karbon } \\
(\text { mesh })\end{array}$ & $\begin{array}{c}\text { Berat arang } \\
\text { (gr) }\end{array}$ & $\begin{array}{c}\text { Berat perekat } \\
(\mathrm{gr})\end{array}$ & $\begin{array}{c}\text { Nilai kalor } \\
(\text { kal/gram })\end{array}$ \\
\hline 50 & 50 & 25 & 27022 \\
50 & 100 & 25 & 27314 \\
50 & 150 & 25 & 26651 \\
80 & 50 & 25 & 27661 \\
80 & 100 & 25 & 29327 \\
80 & 150 & 25 & 27261 \\
\hline
\end{tabular}

\section{Simpulan}

Dari hasil kajian dapat disimpulkan bahwa limbah tempurung kelapa dengan menggunakan getah rumbia sebagai perekat dapat dimanfaatkan menjadi briket arang. Ukuran partikel (mesh) dan berat perekat sangat mempengaruhi kualitas briket yang dihasilkan dari arang tempurung kelapa. Kondisi terbaik briket didapatkan pada ukuran partikel 80 mesh dan 25 gr perekat dengan nilai kalor yang dihasilkan $29327 \mathrm{kal} / \mathrm{gram}$.

Dalam pembuatan briket, moistur briket (kadar air) sangat dipengaruhi oleh perbandingan antara perekat dengan serbuk arang yang digunakan. Penggunaan kadar perekar 35 gr dalam serbuk arang 150 gram dengan ukuran serbuk arang 50 mesh menghasilkan kadar air yang paling rendah yaitu 7,4\%. Sedangkan untuk ukuran serbuk arang 80 mesh adalah $6,4 \%$. 


\section{Daftar Pustaka}

1. Triono, A. 2006. Karakteristik Briket Arang Dari Campuran Serbuk Gergajian Kayu Afrika (Maesopsis eminii Engl) dan Sengon (Paraserianthes falcataria L. Nielsen) dengan Penambahan Tempurung Kelapa (Cocosnucifera L). Skripsi Strata-1 Institut Pertanian Bogor. Bogor.

2. Sutiyono, 2002. Pembuatan Briket Arang dari Tempurung Kelapa dengan Bahan Pengikat Tetes Tebu dan Tapioka. Jurnal Kimia dan Teknologi. Surabaya: Jurusan Teknik Kimia Fakultas Teknologi Indutri-UPN Veteran.

3. Lestari, L., Aripin, Yanti, Zainudin, Sukmawati, Marliani. 2010. Analisis Kualitas Briket Arang Tongkol Jagung Yang Menggunakan Bahan Perekat Sagu dan Kanji, Jurnal aplikasi fisika, 6(2): 93-96.

4. Obi, O. F. 2015. Evaluation of the Effect of Palm Oil Mill Sludge on the Properties of Sawdust Briquette. Renewable and Sustainable Energy Reviews $52: 1749-1758$.

5. Santosa, R. Mislaini, dan S.P. Anugrah. 2010, Studi Variasi Komposisi bahan Penyusun Briket dari Kotoran Sapi dan Limbah Pertanian, Jurusan Teknik Pertanian, Fakultas Teknologi Pertanian Universitas Andalas.

6. Maryono, Sudding dan Rahmawati. 2013. Pembuatan dan Analisis Mutu Briket Arang Tempurung Kelapa Ditinjau dari Kadar Kanji. Jurnal Chemica. 14 (1): $74-83$.

7. Hapis dan Bisrul. 2008. Karakteristik Pembakaran Briket Cangkang Kerniri: Pengaruh Persentase Arang. Jurusan Teknik Mesin Fakultas Teknik Universitas Negeri Medan.

8. Ristianingsih, Y., A. Ulfa, dan R.K.S. Syafitri. 2015. Pengaruh Suhu dan Konsentrasi Perekat Terhadap Karakteristik Briket Bioarang Berbahan Baku Tandan Kosong Kelapa Sawit dengan Proses Pirolisis, Konversi, 4 (2):16-22. 